\title{
Electron Backscatter Diffraction: principles and application.
}

\author{
$\underline{\text { André Luis Pinto }}$ \\ $(C B P F)$
}

\begin{abstract}
O uso da Difração de Elétron Retroespalhado, "Electron Backscatter Diffraction" tem sido amplamente utilizado no estudo de orientação preferencial em aços e ligas. Em especial nota-se certo grau de desconhecimento sobre como utilizar essa técnica de forma mais universal e atingindo maior público da área científica e técnica. O objetivo deste mini curso é o de ampliar o conhecimento dos participantes sobre a mesma, observando os conceitos básicos e suas aplicações. Em especial, aplicações na indústria do aço.
\end{abstract}

